\title{
Physicochemical Assessment of Soil Deterioration in Bukan Sidi and New Garage Auto- Mechanic Villages within Lafia Metropolis, Nasarawa State, Nigeria
}

\author{
A.K. Ibrahim, C.U. Aguoru, A. Onekutu, O.J. Olasan* \\ Environmental Science/Plant Biotechnology/Genetics Unit, Department of Botany, Federal University of Agriculture, Makurdi, Nigeria.
}

\section{ART ICLEDETAILS}

\section{Article history:}

Received 21 May 2019

Accepted 05 July 2019

Available online 21 August 2019

\section{Keywords:}

Auto-Mechanics

Deterioration

Soil

Physicochemical Parameters

\begin{abstract}
A B S T R A C T
The level of soil pollution and deterioration was investigated in two auto-mechanic villages (Bukan Sidi and New Garage) within Lafia metropolis of Nasarawa State, Nigeria. Physicochemical parameters were analysed based on standard protocols. Total organic carbon in the mechanic villages was higher than in the control site; the highest was $1.58 \%$ at $0-10 \mathrm{~cm}$ depths of the two mechanic sites. Available phosphorus was $5.27 \pm 0.085$ on the average ranging from $4.57 \mathrm{ppm}$ to $6.02 \mathrm{ppm}$ with significant differences across locations $(\mathrm{F}=14541.65, \mathrm{P}=0.000)$. Magnesium was the lowest among all inorganic elements $(0.05 \pm 0.008)$ with its maximum value at New garage. Phosphorus, potassium, sodium and calcium recorded highest mean values at Bukan sidi. The mean sodium at $0-10 \mathrm{~cm}$ depth of Bukan Sidi $(0.32 \pm 0.003)$ was the highest recorded in three locations. The concentrations of all elements in soils of the two mechanic sites are significantly higher than those in the control site. Soil exchangeable acidity (EA) values in the mechanic villages are very low compared to the control sit; it ranged from 0.3 to 0.83 Meq/100 g. Bukan Sidi had the highest mean C.E.C of $2.85 \pm 0.003$ at $20-30 \mathrm{~cm}$ depth. Significant differences exist in the distribution of soil particles across locations $(\mathrm{P}<0.05)$. The soil physicochemical parameters of the mechanic sites had significantly different values from those of the control. Results were also higher than the maximum permissible limits of FEPA. Environmental education should be encouraged. Those working in the two mechanic villages should be enlightened on the implication of escalated level of manganese and lead as a result of their daily impact on the soils. Strict compliance to regulatory limits of waste generated from these auto-mechanic villages is recommended.
\end{abstract}

\section{Introduction}

Soil is a crucial abiotic component of the natural environment, constituting the edaphic factor of the ecosystem. The quality of soil also depends on some physicochemical parameters [1]. Thus, proper land use and management is the key to the maintenance of good soil quality. Major causes of soil degeneration are anthropogenic activities. For instance, it is a common practice in Nigeria to allocate large tracts of land for automechanic activities [2]. These areas are designated as mechanic villages where automobile repair services are offered to the public and there are environmental threats associated with this practice [2]. The activities performed in auto-mechanic villages include: spilling of oil, grease, diesel, paints and other materials which contain heavy metals into the bare soil [3]. Pollution from auto-mechanic villages has reached a disturbing level, where those that live close to the area are affected by the presence of heavy metals in their water sources as these contaminants flow down into the water table and land for agriculture is rendered barren [2]. The present study investigated the level of degeneration of soils in two major auto-mechanic villages in Lafia metropolis Nasarawa State, Nigeria.

\section{Experimental Methods}

\subsection{Study Area}

The study was conducted in Lafia metropolis, Lafia local government area. It is one the 13 local government areas in Nasarawa State. Lafia town is bounded by Latitude $8^{\circ} 25^{\prime}$ and Longitude $8^{0} 28^{\prime} \mathrm{E}$. The soils are generally dark and brownish in colour which suggests the presence of microbial activities that support agricultural production.

\subsection{Sampling Locations}

Two auto-mechanic villages were selected as experimental sites. They were: Bukan Sidi mechanic village (Jos Road) and New Garage mechanic village (Makurdi Road). The Botanical Garden of the Faculty of Agriculture (Faculty of Agriculture, Lafia Nasarawa State University) was chosen as the control site devoid of heavy metal pollutants under consideration.

\subsection{Sample Collection and Treatment}

Three sampling points were randomly marked per location. Soil samples were collected using the depth calibrated soil auger. Collection was done from four (4) depths per sampling points: $0-10 \mathrm{~cm}, 10-20 \mathrm{~cm}$, 20-30 cm and 30-40 cm. Soil samples were obtained in triplicates from the composite. Thus, a total of 36 soil samples were collected from the three study areas, 12 per location. Soil samples were collected in labeled polythene bags and labeled using masking tape and permanent markers. Depths of collections were clearly written on each sample bag. The following codes were used for ease of identification: BS= Bukan Sidi, NG= New Garage, CT $=$ Control site. Soil samples were transported to the Agronomy Laboratory of faculty of Agriculture, Lafia, Nasarawa State University. All soil samples were subsequently air-dried to constant weight to avoid microbial degradation [4]. They were homogenized, made lump free by gently crushing repeatedly using and acid pre-washed mortar and pestle, and passed through a $2 \mathrm{~mm}$ plastic sieve prior to analysis.

\subsection{Laboratory Analysis}

Five grams ( $5 \mathrm{~g}$ ) of sample was taken from the sieved soil and put into the beaker contains $10 \mathrm{~mol}$ of nitric acid (2:1) for digestion. $\mathrm{HCl}$ and distilled water ratio 1:1 was added to the digestate. The mixture was transferred to the digester again for 30 minutes. The digestate was then removed from the digester and allowed to cool at room temperature. The cool digestate was washed into a standard volumetric flask and was made up to the mark with distilled water [5]. 


\subsection{Soil Water $\mathrm{pH}$}

Twenty (20 g) of soil was weighed and transferred into $100 \mathrm{~mL}$ beaker containing $40 \mathrm{~mL}$ of distilled. The mixture was stirred with a glass rod and allowed to stand for half an hour (30 minutes). The electrode was immersed and $\mathrm{pH}$ value was determined from the automatic display of the pH meter (Model 3510).

\subsection{Total Organic Matter and Total Organic Carbon}

These were measured by-wet acid digestion [6]. One gram (1 g) of soil sample was weighed in $500 \mathrm{~mL}$ conical flask containing $10 \mathrm{~mL}$ of $1 \mathrm{~N}$ $\mathrm{K}_{2} \mathrm{Cr}_{2} \mathrm{O}_{7}$. Twenty milliliter $(20 \mathrm{~mL})$ of concentrated sulphuric acid was added to the same flask, swirled and allowed to cool for 30 minutes. Distilled (200 mL) water was added plus $10 \mathrm{~mL}$ of orthophoric acid and 1 $\mathrm{g}$ of $\mathrm{Na}$ and $\mathrm{NH}_{4} \mathrm{~F}$. Mixture was allowed to cool. Diphenylamine $(1 \mathrm{~mL}$ of $1 \%$ ) was used as an indicator. Blank was prepared containing numbers 2 to 5 in the different $500 \mathrm{~mL}$ conical flask. Blank and soil samples with $1 \mathrm{~N}$ ferrous sulphate solution were titrated. Calculations of total organic matter and total organic carbon were done and expressed as percentages

\subsection{Available Phosphorus}

The Bray-1 procedure [7] was adopted to check the phosphorus content available. Two grams ( $2 \mathrm{~g}$ ) of soil in a test-tube and $20 \mathrm{~mL}$ of extracting solution was added to distilled water. It was corked and allowed to settle while filter was also developed. Five milliliter $(5 \mathrm{~mL})$ of filtrates in a $50 \mathrm{~mL}$ of volumetric flask was pipetted. Forty milliliter $(40 \mathrm{~mL})$ of distilled water plus $1 \mathrm{~mL}$ of calcium chlorides of $2.5 \%$ ammonium solutions was added. It was shaken and allowed for 15 minutes. Phosphorus content was quantified in part per million ( $\mathrm{ppm}$ ) using the colorimetric approach at $608 \mathrm{~nm}$ filter.

\subsection{Soil Nitrogen}

Soil sample (10 g) was poured into a $500 \mathrm{~mL}$ Kjeldahl flask containing $20 \mathrm{~mL}$ conc. $\mathrm{H}_{2} \mathrm{SO}_{4}$ and $1 \mathrm{~g}$ of catalyst added to the sample [7]. Kjeldahl digestion was heated until all the traces carbon changed to blue fume. Fifty milliliter $(50 \mathrm{~mL})$ of distilled water was added and allowed to cool. Ten (10) glass beads and $100 \mathrm{~mL}$ of $45 \%$ sodium hydroxide were connected on Kjeldahl distillation assembly. A total of $20 \mathrm{~mL}$ of $2.5 \%$ boric acid with three drops of mixed indicator were added. The set up was connected to electric supply for distillation. The distillate with $\mathrm{N} / 20$ of $\mathrm{HCl}$ was titrated and the result was calculated and expressed as percentages.

\subsection{Exchangeable Acidity (EA)}

This was done using the titration method. Five grams $(5 \mathrm{~g})$ of soil with $1 \mathrm{~N} \mathrm{KCl}$ up to $100 \mathrm{~mL}$ was leached. Leachate $(25 \mathrm{~mL})$ in a conical flask (250 $\mathrm{mL}$ ) was pipetted when the $\mathrm{pH}$ of the soil was less than 5.0. Leachate of 50 $\mathrm{mL}$ was pipetted when the $\mathrm{pH}$ was above 5.0 and then $100 \mathrm{~mL}$ of distilled water was added. Five (5) drops of phenolphthalein indicator was added and titrated with $0.05 \mathrm{~N}$. Sodium hydroxide was applied to impregnate the pink (exchangeable acidity). The same flask colour was cleared by addition of $1 \mathrm{~mL}$ of $0.05 \mathrm{~N}$. Hydrogen chloride $(10 \mathrm{~mL})$ with $1 \mathrm{~N} \mathrm{NaF}$ was added and titrated again with $0.05 \mathrm{~N} \mathrm{HCl}$ to obtain colourless end point. E.A values were expressed in Meq/100 g

\subsection{Cation Exchange Capacity (C.E.C)}

Ten grams $(10 \mathrm{~g})$ of soil sampled in a folded filter paper was inserted in a funnel fixed on the leaching rack. Leached soil of $10 \mathrm{~g}$ was poured into a $250 \mathrm{~mL}$ volumetric flask containing $1 \mathrm{~N} \mathrm{NH}_{4} 0 \mathrm{AC}(\mathrm{pH} \mathrm{7.0})$ and fixed on the rack. The residue in the filter paper/filter funnel was allowed to dry by air for 24 hours. The residue treated with 75 to $150 \mathrm{~mL}$ of methanol was allowed to dry again in air. Leaching was repeated in $0.1 \mathrm{~N} \mathrm{KCl}$ solution in a $250 \mathrm{~mL}$ capacity. Thereafter, $1 \mathrm{~N} \mathrm{NH}_{4} 0 \mathrm{AC}$ leachate was used to determine the $\mathrm{Na}, \mathrm{K}, \mathrm{Ca}$ and $\mathrm{Mg}$ content while $0.1 \mathrm{~N} \mathrm{KCl}$ was also used to determine the $\mathrm{CEC}$ and expressed in $\mathrm{Cmol} / \mathrm{kg}$.

\subsection{Particles size analysis}

Particles size analysis was determined by the hydrometer method using sodium hexametaphosphate and sodium carbonates (calgon) as the dispensant. Textural class determination was done using the USDA textural triangle [8]. Percentages of clay, silt, fine sand and coarse sand of the soil sample were obtained.

\subsection{Data Analysis}

Data analysis was done on the Minitab Software (16.0 version). Quantitative variables were described for mean values and standard error of the mean, Inferences were conducted on each physicochemical property https://doi.org/10.30799/jespr.169.19050302 using the two-way analysis of variance (Two Way ANOVA) tool which determined levels of significant differences among the three locations and the four depths with interaction effects. Means separation was done using the Fischer's method at 0.05 level of significance ( $95 \%$ confidence limit).

\section{Results and Discussion}

Comparative soil water $\mathrm{pH}$ of the three locations is given in Table 1 . The three sampling sites differed significantly in soil water $\mathrm{pH}(\mathrm{F}=5380.4$, $\mathrm{P}=0.000$ ) as the control site was different from the mechanic villages. The control site had the highest $\mathrm{pH}$ grand value of 7.24 followed by Bukan Sidi (7.11) and New Garage with acidic $\mathrm{pH}$ of 6.59. The four depth zones also differed significantly $(\mathrm{F}=763.5, \mathrm{P}=0.000)$ as separated by $10-20 \mathrm{~cm}$ being lower in $\mathrm{pH}$ than in other zones (Grand mean=6.76). Significant $\mathrm{pH}$ interaction effect exists between location and soil depth $(\mathrm{F}=584.51$, $\mathrm{P}=0.000)$. At the surface soil $(0-10 \mathrm{~cm})$, New Garage site had a mean $\mathrm{pH}$ of $7.21 \pm 0.012$ as the highest followed by Bukan Sidi $(7.07 \pm 0.009)$ and the control site $(6.92 \pm 0.012)$ as the least.

Table $1 \mathrm{pH}$ of water samples in the three study sites

\begin{tabular}{llll}
\hline Depth/Locations & Bukan Sidi & New Garage & Control site \\
\hline $0-10 \mathrm{~cm}$ & $7.07 \pm 0.009^{\mathrm{a}}$ & $7.21 \pm 0.012^{\mathrm{a}}$ & $6.92 \pm 0.012^{\mathrm{b}}$ \\
$10-20 \mathrm{~cm}$ & $6.93 \pm 0.012^{\mathrm{b}}$ & $6.84 \pm 0.015^{\mathrm{b}}$ & $6.50 \pm 0.008^{\mathrm{c}}$ \\
$20-30 \mathrm{~cm}$ & $7.20 \pm 0.009^{\mathrm{a}}$ & $7.41 \pm 0.006^{\mathrm{a}}$ & $6.62 \pm 0.009^{\mathrm{b}}$ \\
$30-40 \mathrm{~cm}$ & $7.23 \pm 0.006^{\mathrm{a}}$ & $7.51 \pm 0.006^{\mathrm{a}}$ & $6.30 \pm 0.003^{\mathrm{b}}$ \\
\hline
\end{tabular}

Location: $F=5380.4, P=0.00$; Depth: $F=763.5, P=0.00$; Interaction: $F=584.51, P=0.00$ Note: Means with different letters are significantly different

Values of soil organic carbon (O.C) across the three locations and depths are given in Table 2. The highest organic carbon content was $1.58 \%$ recorded at $0-10 \mathrm{~cm}$ soil surfaces of the two mechanic villages. At this level, the control site had a mean value of $1.30 \pm 0.003$. The lowest O.C value occurred at the deepest depth of $30-40 \mathrm{~cm}$ in New Garage site with a mean value of $1.23 \pm 0.003$. Significant differences exist in the percentage 0.C of the soil locations $(\mathrm{F}=15.56, \mathrm{P}=0.000)$. Mean separation is caused by the values recorded at Buka-sidi site. O.C values also differ significantly along the soil depths as separated by two zones: $20-30 \mathrm{~cm}$ and $30-40 \mathrm{~cm}$. The later depth had lower \%O.C than the former.

Table 2 Percentage organic carbon of soil samples in the three study sites

\begin{tabular}{lccl}
\hline Depth/Locations & $\begin{array}{c}\text { Bukan Sidi } \\
\% 0 . C\end{array}$ & $\begin{array}{c}\text { New Garage } \\
\% 0 . C\end{array}$ & $\begin{array}{l}\text { Control site } \\
\% 0 . C\end{array}$ \\
\hline $0-10 \mathrm{~cm}$ & $1.58 \pm 0.006^{\mathrm{a}}$ & $1.58 \pm 0.006^{\mathrm{b}}$ & $1.30 \pm 0.003^{\mathrm{b}}$ \\
$10-20 \mathrm{~cm}$ & $1.43 \pm 0.006^{\mathrm{a}}$ & $1.40 \pm 0.012^{\mathrm{b}}$ & $1.44 \pm 0.003^{\mathrm{b}}$ \\
$20-30 \mathrm{~cm}$ & $1.44 \pm 0.012^{\mathrm{b}}$ & $1.55 \pm 0.003^{\mathrm{c}}$ & $1.56 \pm 0.003^{\mathrm{c}}$ \\
$30-40 \mathrm{~cm}$ & $1.38 \pm 0.003^{\mathrm{c}}$ & $1.23 \pm 0.003^{\mathrm{d}}$ & $1.44 \pm 0.006^{\mathrm{d}}$ \\
\hline
\end{tabular}

Location: $F=15.56, P=0.00$; Depth: $F=397.80, P=0.00 ; \quad$ Interaction: $F=340.98, P=0.00$ Note: Means with different letters are significantly different

Values of soil organic matter (OM) content of the sampling locations are shown in Table 3. At a depth of $0-10 \mathrm{~cm}, 0 M$ was $2.72 \pm 0.009$ and $2.71 \pm 0.007$ in the two mechanic sites but $2.24 \pm 0.006$ in the control site. At deeper depths $(30-40 \mathrm{~cm}), \mathrm{OM}$ of the mechanic villages decreased significantly to $2.37 \%$ and $2.11 \%$ in Bukan Sidi and New Garage respectively but increased in the control site to $2.48 \%$. Therefore, significant differences were observed in the OM content of the three locations as separated by the Bukan Sidi soil $(F=15.89, P=0.000)$ with a Grand Mean of $2.51 \%$ OM being higher than the two other locations. The four depths also differ significantly in OM content as separated by the two deeper zones. The 20-30 cm depth recorded the highest Grand Mean of $2.61 \%$ of organic matter.

Table 3 Percentage organic matter of soil samples in the three study sites

\begin{tabular}{llll}
\hline Depth/Locations & $\begin{array}{l}\text { Bukan Sidi } \\
\% O M\end{array}$ & $\begin{array}{l}\text { New Garage } \\
\% O M\end{array}$ & $\begin{array}{l}\text { Control site } \\
\% 0 M\end{array}$ \\
\hline $0-10 \mathrm{~cm}$ & $2.72 \pm 0.009^{\mathrm{a}}$ & $2.71 \pm 0.007 \mathrm{~b}$ & $2.24 \pm 0.006^{\mathrm{b}}$ \\
$10-20 \mathrm{~cm}$ & $2.44 \pm 0.015^{\mathrm{a}}$ & $2.41 \pm 0.020^{\mathrm{b}}$ & $2.49 \pm 0.007^{\mathrm{b}}$ \\
$20-30 \mathrm{~cm}$ & $2.51 \pm 0.003^{\mathrm{b}}$ & $2.66 \pm 0.007^{\mathrm{c}}$ & $2.68 \pm 0.006^{\mathrm{c}}$ \\
$30-40 \mathrm{~cm}$ & $2.37 \pm 0.012^{\mathrm{c}}$ & $2.11 \pm 0.012^{\mathrm{d}}$ & $2.48 \pm 0.012^{\mathrm{d}}$ \\
\hline
\end{tabular}

Location: $F=15.89, P=0.00$; Depth: $F=449.32, P=0.00$; Interaction: $F=350.43, P=0.00$

Note: Means with different letters are significantly different

Table 4 presents the percentage nitrogen content of the soils across locations and depths. All the locations behaved alike as the nitrogen contents are not significantly different $(\mathrm{F}=1.47, \mathrm{P}=0.249)$ across the locations and down the soil depths $(\mathrm{F}=1.08, \mathrm{P}=0.377)$. No significant interaction exists between the location and soil depth. However, New 
Garage soil contained slightly more nitrogen at $0-10 \mathrm{~cm}(0.36 \pm 0.007)$ and $20-30 \mathrm{~cm}(0.34 \pm 0.003)$. The control site had the highest amount of soil nitrogen localized in the deep soil of $30-40 \mathrm{~cm}$ with an average value of $0.48 \pm 0.327$.

Table 4 Percentage nitrogen of soil samples in the three study sites

\begin{tabular}{llll}
\hline Depth/Locations & $\begin{array}{l}\text { Bukan Sidi } \\
\% \mathrm{~N}\end{array}$ & $\begin{array}{l}\text { New Garage } \\
\% \mathrm{~N}\end{array}$ & $\begin{array}{l}\text { Control site } \\
\% \mathrm{~N}\end{array}$ \\
\hline $0-10 \mathrm{~cm}$ & $0.28 \pm 0.000^{\mathrm{a}}$ & $0.36 \pm 0.007^{\mathrm{a}}$ & $0.15 \pm 0.007^{\mathrm{a}}$ \\
$10-20 \mathrm{~cm}$ & $0.28 \pm 0.003^{\mathrm{a}}$ & $0.28 \pm 0.003^{\mathrm{a}}$ & $0.14 \pm 0.006^{\mathrm{a}}$ \\
$20-30 \mathrm{~cm}$ & $0.21 \pm 0.003^{\mathrm{a}}$ & $0.34 \pm 0.003^{\mathrm{a}}$ & $0.15 \pm 0.003^{\mathrm{a}}$ \\
$30-40 \mathrm{~cm}$ & $0.22 \pm 0.003^{\mathrm{a}}$ & $0.36 \pm 0.008^{\mathrm{a}}$ & $0.48 \pm 0.327^{\mathrm{a}}$ \\
\hline
\end{tabular}

Location: $F=1.47, P=0.249$; Depth: $F=1.08, P=0.377$; Interaction: $F=1.17, P=0.354$

Note: Means with different letters are significantly different

Available soil phosphorus is given in Table 5. Phosphorus was relatively higher in Bukan Sidi soil of various depths than in other locations. The 0$10 \mathrm{~cm}$ depths contained average phosphorus of $5.68 \pm 0.006$ at Bukan Sidi, $5.21 \pm 0.003$ at New Garage and $4.86 \pm 0.003$ at the control site as the least. Phosphorus level increased progressively down the soil depth in the Bukan Sidi soil. In the deep soil interior within 30-40 cm depth, average phosphorus content was $6.013 \pm 0.003$ at Bukan Sidi (the highest value recorded) followed by $5.21 \pm 0.003$ at New Garage and $4.57 \pm 0.003$ at the control site. Significant differences exist in the available phosphorus of the three locations $(\mathrm{F}=14541.65, \mathrm{P}=0.000)$ separated by the lower values of the control site. The soil depths are also different in the phosphorus content $(\mathrm{F}=9.94, \mathrm{P}=0.000)$ being low at the upper soil surface $(0-10 \mathrm{~cm})$ with a grand mean of $5.25 \mathrm{ppm}$. Significant interaction exists between locations and their soil depths $(\mathrm{F}=206.93, \mathrm{P}=0.000)$

Table 5 Available phosphorus of soil samples in the three study sites

\begin{tabular}{llll}
\hline Depth/Locations & $\begin{array}{l}\text { Bukan Sidi } \\
\text { Avail P }(\mathrm{ppm})\end{array}$ & $\begin{array}{l}\text { New Garage } \\
\text { Avail P }(\mathrm{ppm})\end{array}$ & $\begin{array}{l}\text { Control site } \\
\text { Avail P }(\mathrm{ppm})\end{array}$ \\
\hline $0-10 \mathrm{~cm}$ & $5.68 \pm 0.006^{\mathrm{a}}$ & $5.21 \pm 0.003^{\mathrm{a}}$ & $4.86 \pm 0.003^{\mathrm{b}}$ \\
$10-20 \mathrm{~cm}$ & $5.97 \pm 0.003^{\mathrm{b}}$ & $5.12 \pm 0.003^{\mathrm{b}}$ & $4.79 \pm 0.003^{\mathrm{c}}$ \\
$20-30 \mathrm{~cm}$ & $5.98 \pm 0.007^{\mathrm{b}}$ & $5.18 \pm 0.032^{\mathrm{b}}$ & $4.67 \pm 0.003^{\mathrm{c}}$ \\
$30-40 \mathrm{~cm}$ & $6.013 \pm 0.003^{\mathrm{b}}$ & $5.21 \pm 0.003^{\mathrm{b}}$ & $4.57 \pm 0.003^{\mathrm{c}}$ \\
\hline
\end{tabular}

Location: $F=14541.65, P=0.00$; Depth: $F=9.94, P=0.00$; Interaction: $F=206.93, P=0.00$ Note: Means with different letters are significantly different

The Bukan Sidi soil contained more potassium than other locations (Table 6). The control site contained the least amount of potassium. The 0$10 \mathrm{~cm}$ depth contained average potassium of $0.42 \pm 0.003$ in Buka-Sidi followed by $0.39 \pm 0.003$ in New Garage and $0.30 \pm 0.006$ in the control site. Across the three locations, the deep soil $(30-40 \mathrm{~cm})$ contained mean potassium of $0.45 \pm 0.003,0.37 \pm 0.009$ and $0.33 \pm 0.003$ respectively. Significant differences exist in the potassium content across the three locations $(\mathrm{F}=605.62, \mathrm{P}=0.000)$ with grand mean separation of $0.44 \mathrm{ppm}$ at Bukan Sidi and $0.31 \mathrm{ppm}$ of the control site. The soil depths also recorded significant differences in potassium content. Separation was attributed to the low potassium of the soil surface within $0-10 \mathrm{~cm}$ (grand mean $=0.372$ $\mathrm{ppm}$ ) and the high content of the deep soil within 30-40 cm (grand mean $=0.384 \mathrm{ppm}$ ).

Table 6 Potassium content of soil samples in the three study sites

\begin{tabular}{llll}
\hline Depth/Locations & $\begin{array}{l}\text { Bukan Sidi } \\
\text { Cmol } / \mathrm{kg} \mathrm{K}\end{array}$ & $\begin{array}{l}\text { New Garage } \\
\text { Cmol } / \mathrm{kg} \mathrm{K}^{\mathrm{a}}\end{array}$ & $\begin{array}{l}\text { Control site } \\
\text { Cmol } / \mathrm{kg} \mathrm{K}^{\mathrm{a}}\end{array}$ \\
\hline $0-10 \mathrm{~cm}$ & $0.42 \pm 0.003^{\mathrm{a}}$ & $0.39 \pm 0.003^{\mathrm{b}}$ & $0.30 \pm 0.006^{\mathrm{c}}$ \\
$10-20 \mathrm{~cm}$ & $0.46 \pm 0.003^{\mathrm{b}}$ & $0.38 \pm 0.006^{\mathrm{c}}$ & $0.31 \pm 0.006^{\mathrm{d}}$ \\
$20-30 \mathrm{~cm}$ & $0.43 \pm 0.003^{\mathrm{a}}$ & $0.37 \pm 0.007^{\mathrm{b}}$ & $0.32 \pm 0.006^{\mathrm{c}}$ \\
$30-40 \mathrm{~cm}$ & $0.45 \pm 0.003^{\mathrm{b}}$ & $0.37 \pm 0.009^{\mathrm{c}}$ & $0.33 \pm 0.003^{\mathrm{d}}$ \\
\hline
\end{tabular}

Location: $F=605.62, P=0.000 ;$ Depth: $F=3.62, P=0.000$; Interaction: $F=7.14, P=0.000$

Note: Means with different letters are significantly different

Table 7 presents the sodium content of the soil samples. The two mechanic villages contained soils with higher amount of sodium than the control site along the various soil depths. The mean sodium at $0-10 \mathrm{~cm}$ of Bukan Sidi was $0.32 \pm 0.003$ as the highest recorded in three locations. Sodium was $0.29 \mathrm{Cmol} / \mathrm{kg}$ at New Garage soil and $0.26 \mathrm{Cmol} / \mathrm{kg}$ at the control site. The sub soil $(30-40 \mathrm{~cm})$ contained $0.31 \pm 0.010,0.30 \pm 0.003$ and $0.27 \pm 0.003$ mean sodium in the three locations respectively. Differences in the amount of sodium are significant across the locations $(\mathrm{F}=127.95, \mathrm{P}=0.000)$ and depths $(\mathrm{F}=5.13, \mathrm{P}=0.007)$. Mean separation was caused by the lower amount of sodium at the control site and depth of 20$30 \mathrm{~cm}$. Calcium content of soil samples is given in Table 8 . The three sites contained different amounts of calcium at different depths. The highest amount was observed at Bukan Sidi with mean value of $2.06 \pm 0.003$ at a depth of 20-30 cm. The least amount was present at the control site with https://doi.org/10.30799/jespr.169.19050302 mean value of $0.74 \pm 0.022$ within the top soil $(0-10 \mathrm{~cm})$. Differences in the amount of calcium are statistically significant across the three sites $(\mathrm{F}=7717.04, \mathrm{P}=0.000)$ and depths $(\mathrm{F}=909.89, \mathrm{P}=0.000)$ with significant interaction effects $(\mathrm{F}=3312.13, \mathrm{P}=0.000)$. The control site had lower calcium contents than other sites. The top soils contained lesser amount of calcium than the sub soils.

Table 7 Sodium content of soil samples in the three study sites

\begin{tabular}{llll}
\hline Depth/Locations & $\begin{array}{l}\text { Bukan Sidi } \\
\text { Cmol } / k g ~ N a\end{array}$ & $\begin{array}{l}\text { New Garage } \\
\text { Cmol/kg Na }\end{array}$ & $\begin{array}{l}\text { Control site } \\
\text { Cmol } / k g ~ N a\end{array}$ \\
\hline $0-10 \mathrm{~cm}$ & $0.32 \pm 0.003^{\mathrm{a}}$ & $0.29 \pm 0.000^{\mathrm{a}}$ & $0.26 \pm 0.003^{\mathrm{b}}$ \\
$10-20 \mathrm{~cm}$ & $0.31 \pm 0.003^{\mathrm{a}}$ & $0.30 \pm 0.003^{\mathrm{a}}$ & $0.27 \pm 0.003^{\mathrm{b}}$ \\
$20-30 \mathrm{~cm}$ & $0.31 \pm 0.000^{\mathrm{b}}$ & $0.28 \pm 0.003^{\mathrm{b}}$ & $0.26 \pm 0.006^{\mathrm{c}}$ \\
$30-40 \mathrm{~cm}$ & $0.31 \pm 0.010^{\mathrm{a}}$ & $0.30 \pm 0.003^{\mathrm{a}}$ & $0.27 \pm 0.003^{\mathrm{b}}$ \\
\hline
\end{tabular}

Location: $F=127.95, P=0.000 ;$ Depth: $F=5.13, P=0.007$; Interaction: $F=3.28, P=0.017$

Note: Means with different letters are significantly different

Table 8 Calcium content of soil samples in the three study sites

\begin{tabular}{llll}
\hline Depth/Locations & $\begin{array}{l}\text { Bukan Sidi } \\
\text { Cmol } / \mathrm{kg} \mathrm{Ca}\end{array}$ & $\begin{array}{l}\text { New Garage } \\
\text { Cmol/kg Ca }\end{array}$ & $\begin{array}{l}\text { Control site } \\
\text { Cmol } / \mathrm{kg} \mathrm{Ca}\end{array}$ \\
\hline $0-10 \mathrm{~cm}$ & $1.96 \pm 0.003 \mathrm{a}$ & $0.95 \pm 0.00^{\mathrm{b}}$ & $0.74 \pm 0.022^{\mathrm{b}}$ \\
$10-20 \mathrm{~cm}$ & $1.61 \pm 0.000^{\mathrm{b}}$ & $1.62 \pm 0.003^{\mathrm{c}}$ & $1.05 \pm 0.003^{\mathrm{c}}$ \\
$20-30 \mathrm{~cm}$ & $2.06 \pm 0.003^{\mathrm{b}}$ & $1.18 \pm 0.003^{\mathrm{c}}$ & $1.18 \pm 0.003^{\mathrm{c}}$ \\
$30-40 \mathrm{~cm}$ & $1.25 \pm 0.000^{\mathrm{b}}$ & $1.48 \pm 0.003^{\mathrm{c}}$ & $1.58 \pm 0.000^{\mathrm{c}}$ \\
\hline Location: $F=7717.04, P=0.0 \cdot$ Depth $F=909.89, P=0.0 ;$ Interaction: $F=3312.13, P=0.0$
\end{tabular}

Location: F=7717.04, $P=0.0$; Depth: $F=909.89, P=0.0 ;$ Intera

Table 9 gives the magnesium content present in the soil samples. Lowest amount was present in the sub soil of New Garage with 0.03 $\mathrm{Cmol} / \mathrm{kg}$ while the highest amount was present in the sub soil of the control site with $1.58 \mathrm{Cmol} / \mathrm{kg}$. Differences observed in the magnesium are not significant across the locations $(\mathrm{F}=1.33, \mathrm{P}=0.284)$ and depths $(\mathrm{F}=1.13$ $\mathrm{P}=0.358)$. On average, New Garage contained the highest amount of magnesium followed by Bukan Sidi. Control site had the least amount. The 10-20 cm depths contained the highest amount of magnesium. The Exchangeable Acidity (EA) of soil samples is presented in Table 10. Control Site had the highest EA across the depths being maximum in the $30-40 \mathrm{~cm}$ sub soil with $0.82 \mathrm{Meq} / 100 \mathrm{~g}$. The control site was responsible for the significant differences observed in the EA values of the soil samples $(\mathrm{F}=20.64, \mathrm{P}=0.000)$. The mean EA at Bukan Sidi and New Garage are 0.4 Meq/100 $\mathrm{g}$ and $0.56 \mathrm{Meq} / 100 \mathrm{~g}$ respectively as shown in Fig. 7. Differences along the soil depths are not significantly different $(F=2.49$, $\mathrm{P}=0.085$ ) although EA tends to be more within 10-20 $\mathrm{cm}$ depth.

Table 9 Magnesium content of soil samples in the three study sites

\begin{tabular}{llll}
\hline Depth/Locations & $\begin{array}{l}\text { Bukan Sidi } \\
\text { Cmol } / \mathrm{kg} \mathrm{Mg}\end{array}$ & $\begin{array}{l}\text { New Garage } \\
\text { Cmol } / \mathrm{kg} \mathrm{Mg}\end{array}$ & $\begin{array}{l}\text { Control site } \\
\text { Cmol } / \mathrm{kg} \mathrm{Mg}\end{array}$ \\
\hline $0-10 \mathrm{~cm}$ & $0.05 \pm 0.003^{\mathrm{a}}$ & $0.04 \pm 0.003^{\mathrm{a}}$ & $0.74 \pm 0.022^{\mathrm{a}}$ \\
$10-20 \mathrm{~cm}$ & $0.06 \pm 0.006^{\mathrm{a}}$ & $0.13 \pm 0.095^{\mathrm{a}}$ & $1.05 \pm 000^{\mathrm{a}}$ \\
$20-30 \mathrm{~cm}$ & $0.05 \pm 0.003^{\mathrm{a}}$ & $0.05 \pm 0.000^{\mathrm{a}}$ & $1.18 \pm 0.03^{\mathrm{a}}$ \\
$30-40 \mathrm{~cm}$ & $0.05 \pm 0.003^{\mathrm{a}}$ & $0.03 \pm 0.003^{\mathrm{a}}$ & $1.58 \pm 0.00^{\mathrm{a}}$ \\
\hline
\end{tabular}

Location: $F=1.33, P=0.284 ; \quad$ Depth: $F=1.13, P=0.358$; Interaction: $F=0.78, P=0.592$ Note: Means with different letters are significantly different

Table 10 Comparative EA of soil samples in the three study sites

\begin{tabular}{llll}
\hline Depth/Locations & $\begin{array}{l}\text { Bukan Sidi } \\
\text { Meq/100 g EA }\end{array}$ & $\begin{array}{l}\text { New Garage } \\
\text { Meq/100 g EA }\end{array}$ & $\begin{array}{l}\text { Control site } \\
\text { Meq/100 g EA }\end{array}$ \\
\hline $0-10 \mathrm{~cm}$ & $0.39 \pm 0.057^{\mathrm{a}}$ & $0.33 \pm 0.000^{\mathrm{a}}$ & $0.50 \pm 000^{\mathrm{b}}$ \\
$10-20 \mathrm{~cm}$ & $0.55 \pm 0.147 \mathrm{a}$ & $0.44 \pm 0.057 \mathrm{a}$ & $0.61 \pm 0.110^{\mathrm{b}}$ \\
$20-30 \mathrm{~cm}$ & $0.33 \pm 0.000^{\mathrm{a}}$ & $0.33 \pm 0.000^{\mathrm{a}}$ & $0.61 \pm 0.110^{\mathrm{b}}$ \\
$30-40 \mathrm{~cm}$ & $0.33 \pm 0.000^{\mathrm{a}}$ & $0.32 \pm 0.010^{\mathrm{a}}$ & $0.82 \pm 0.010^{\mathrm{b}}$ \\
\hline
\end{tabular}

Location: $F=20.64, P=0.000$; Depth: $F=2.49, P=0.085$; Interaction: $F=2.48, P=0.052$ Note: Means with different letters are significantly different

Cation Exchange Capacity of soil samples is given in Table 11. Bukan Sidi had the highest mean C.E.C of $2.85 \pm 0.003$ at $20-30 \mathrm{~cm}$ depth followed by $2.74 \pm 0.003$ at $0-10 \mathrm{~cm}$ in the same location. Soil samples with the lowest C.E.C were found at control site within $0-10 \mathrm{~cm}$ with a mean value of $1.38 \pm 0.006$ followed by $10-20 \mathrm{~cm}$ depth of the same location with mean C.E.C of $1.66 \pm 0.003$. Statistically significant differences exist in the mean C.E.C of locations $(\mathrm{F}=776.96, \mathrm{P}=0.000)$ and depths $(\mathrm{F}=53.38, \mathrm{P}=0.000)$. Mean separation was caused by the high C.E.C value at Bukan Sidi and low values at control sites soil depths.

Based on particle size distribution, the control site had the largest amount of sand (89\% in all depths) followed by $85.8 \%$ in the sub soils of New Garage. The top soil of New Garage and all depths of the Bukan Sidi contained the same amount of sand (82\%). Significant differences exist in the distribution of sand composition of the three sites $(F=64.96, \mathrm{P}=0.000)$. 
The various depths had similar sand composition $(\mathrm{F}=1.00, \mathrm{P}=0.455)$. Silt was lower in control sites than other sites although differences are not significant across locations ( $\mathrm{F}=4.56, \mathrm{P}=0.062)$ and depths $(\mathrm{F}=0.63$, $\mathrm{P}=0.622)$. However, clay contents are significantly different across the locations $(\mathrm{F}=117.0, \mathrm{P}=0.000)$ but the same along the depths $(\mathrm{F}=1.0$, $\mathrm{P}=0.455$ ). Highest amount of clay was present at Buka-Sidi followed by New Garage but the control site had the least amount of silt (Fig. 1).

Table 11 Comparative C.E.C of soil samples in the three study sites

\begin{tabular}{llll}
\hline Depth/Locations & $\begin{array}{l}\text { Bukan Sidi } \\
\text { Cmol/kg C.E.C }\end{array}$ & $\begin{array}{l}\text { New Garage } \\
\text { Cmol } / k g \text { C.E.C }\end{array}$ & $\begin{array}{l}\text { Control site } \\
\text { Cmol } / k g \text { C.E.C }\end{array}$ \\
\hline $0-10 \mathrm{~cm}$ & $2.74 \pm 0.003^{\mathrm{a}}$ & $1.67 \pm 0.003^{\mathrm{b}}$ & $1.38 \pm 0.006^{\mathrm{b}}$ \\
$10-20 \mathrm{~cm}$ & $2.42 \pm 0.003^{\mathrm{b}}$ & $2.42 \pm 0.095^{\mathrm{c}}$ & $1.66 \pm 0.003^{\mathrm{c}}$ \\
$20-30 \mathrm{~cm}$ & $2.85 \pm 0.003^{\mathrm{b}}$ & $1.90 \pm 0.003^{\mathrm{c}}$ & $1.78 \pm 0.003^{\mathrm{c}}$ \\
$30-40 \mathrm{~cm}$ & $2.05 \pm 0.003^{\mathrm{b}}$ & $2.17 \pm 0.003^{\mathrm{c}}$ & $2.19 \pm 0.006^{\mathrm{c}}$ \\
\hline
\end{tabular}

Location: $F=776.96, P=0.00$; Depth: $F=53.38, P=0.00$; Interaction: $F=201.56, P=0.00$

Note: Means with different letters are significantly different

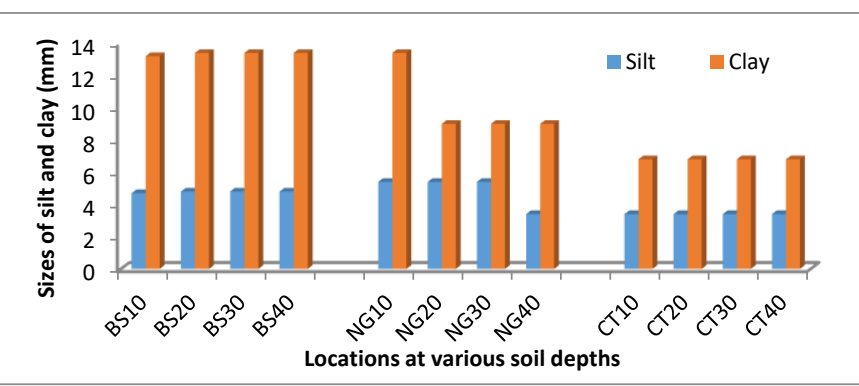

Fig. 1 Silt and clay sizes across study site (Silt: Location: $\mathrm{F}=4.56, \mathrm{P}=0.062$; Depth: $\mathrm{F}=0.63, \mathrm{P}=0.622$; Clay: Location: $\mathrm{F}=117.0, \mathrm{P}=0.000$; Depth:F=1.0, $\mathrm{P}=0.455$ )

The present report has successfully undertaken an environmental audit on the soil components of two auto mechanic sites within Lafia metropolis of Nasarawa State, Nigeria. All indicators pointed out that the locations are heavily polluted and affected by the activities generated by daily automobile repairs and services. Deductions are drawn based on critical analysis and comparison with the control location as well as the maximum tolerable limits of some elements in the environment published by regulatory agencies [9].

Based on pH analysis of soil water, the Bukan Sidi soil and the control site are slightly above neutral moving towards basicity while New garage soil is acidic. This finding has serious implication on the overall life support function of the soils. Acidic soils are injurious to soil organisms [10]. A common feature of this type of soil is a phenomenon called leaching. It is a situation whereby useful mineral elements are washed away from plant roots, hence cannot support plant growth [10]. The entire ecosystem is thus disrupted. Discharge of acids from batteries and other acidic fluids or sprays might be more pronounced in New garage than Bukan Sidi. The presence of some acidic and basic elements present in the analysed soil samples are possible factors accounting for differences in soil $\mathrm{pH}$ of the three locations. The present findings deviate from other reports on polluted samples where the soil $\mathrm{pH}$ was highly acidic or highly alkaline [11, 12]. Wu et al. [13] found a strong association between soil $\mathrm{pH}$ values and heavy metal concentrations as $\mathrm{pH}$ affects bioavailability of elements. Abnormal soil $\mathrm{pH}$ negatively affects soil microbial population, which may have direct negative effect on soil fertility. Exceptions to this are recalcitrant microbes possessing plasmids that contain genes coding for adaptions to extreme acidic or basic conditions [14]. In the present reports, $\mathrm{pH}$ of $\mathrm{CaCl}_{2}$ being relatively lower in the control site than the two mechanic sites have confirmed heavy metal pollution of automobile activities in the two mechanic villages.

Total organic carbon of soils obtained in the mechanic villages are far higher than in soil of the control site. This is possibly due to the presence of organic chemicals and hydrocarbons such as used oil and other carbonated fluid discharged in the auto-mechanic villages. According to [15], this might cause an increase in the presence of specialized soil microorganisms which are in the business of breaking down organic compounds in soils (organotrophic microbes) and loss of other soil microorganisms lacking capacity to adapt. The present report is in line with previous studies where organic carbon was very high in auto mechanic polluted soils in different parts of Nigeria [16, 2].

Analysis of soil organic matter in the study locations surprisingly placed the Bukan Sidi and New garage mechanic sites above the control site. Accumulation of organic carbon elements discharged to the environment is a possible factor. However, it is doubtful if they are in useable forms to support diverse soil biota. Useable soil organic matter, accumulating from plant and animal remains, plays an important role in soil as it improves https://doi.org/10.30799/jespr.169.19050302 both the physical and the chemical properties of soil. It also enhances aeration, water holding capacity and supplies nutrients for the growth of plant and micro-organisms [12]. Phosphorus, potassium, sodium and calcium recorded highest mean values at Bukan Sidi soils. Magnesium had highest value at New garage. The concentrations of the five elements in soils of the two mechanic sites are higher than those in the control site. This is an indication of soil toxicity resulting from excessive accumulation of these elements in the mechanic villages. Based on the five inorganic elements, Bukan Sidi and New garage soils could be described as highly salty. Although plants require these elements for growth, they become toxic when available is more than required amount where they become pollutants. Moreover, activities of the auto mechanic villages might have disrupted the normal biogeochemical cycling of these minerals as reported in other waste disposal affecting characteristic of a functional ecosystem [17]. It is possible that the control site contains moderate amount of these elements necessary for ecosystem function. The control site had the highest amount of soil nitrogen localized in the sub soil. This is expected of soil capable of supporting plant growth. It may be due to the availability of functional soil microorganisms most of which are nitrogen fixers [18].

Soil EA values in the mechanic villages are very low compared to the control site. Exchangeable acidity (EA) confirms the acidic tendencies of soils at the mechanic villages, usually attributed to high concentration of acidic elements and heavy metals pollution [5]. Cation exchange capacity (CEC) of soil samples obtained from the mechanic villages is higher than the control site. The Bukan Sidi had the highest CEC value. This property regulates the mobilisation of heavy metals and it is affected by soil $\mathrm{pH}$ [19].

Distribution of soil particles is different among the studied locations. The control site was characterized by large amount of sand, low silt and little clay. The soils of the mechanic villages are also sandy but silty with large amount of clay. The variation observed in the soils physical properties have pronounced implication on the texture, structure, properties and overall function of the soils [20]. The silty and clay nature of soils at the mechanic villages are indications of soil deterioration largely caused by heavy metal pollutions $[19,20]$ and other activities. Largely, deterioration is known to affect soil function, fertility and level of soil biodiversity [21, 22].

\section{Conclusion}

The soil physicochemical parameters of the mechanic sites had significantly different values from those of the control. Results were also higher than the maximum permissible limits of FEPA (1991). From all indications, automobile activities have resulted into high soil deterioration within and around the studied sites, thus rendering the soil impoverished. Environmental education should be encouraged. Those working in the two mechanic villages should be enlightened on the implication of escalated level of manganese and lead as a result of their daily impact on the soils. Strict compliance to regulatory limits of waste generated from these automechanic villages is recommended.

\section{References}

[1] U.C. Gupta, S.C. Gupta, Trace element toxicity relationship to crop production, Livestock and human health, Commun. Soil Sci. Plant Anal. 29(11-12) (2010) 1491-1522.

[2] B.A. Adelekan, K.D. Abegunde, Heavy metal contamination of soil and groundwater at automobile mechanic villages in Ibadan, Nigeria, Int. J. Phys. Sci. 6(5) (2011) 1045-1058.

[3] K.E. Ayeni, Heavy metals pollution in selected industrial locations, Cont. J. Revenue Ener. 1 (2010) 9-14.

[4] S.E. Kakulu, Biological monitoring of atmospheric trace metal deposition in North-Eastern Nigeria, Environ. Monitor. Assess. 28 (1993) 137-143.

[5] M.B. Adewole, L.U. Uchegbu, Properties of soils and plant uptake within the vicinity of selected Automobile workshops in Ile-Ife South Western, Nigeria, Ethiopian J. Environ. Studies Manag. 3(3) (2010) 372-385.

[6] A. Walkley, I.A. Black, An examination of Degtjareff method for determining soil organic matter and a proposed modification of the chromic acid titration method, Soil Sci. 37 (1934) 29-37.

[7] R.H. Bray, L.T. Kurtz, Determination of total, organic, and available forms of phosphorus in soils, Soil Sci. 59 (1945) 39-45.

[8] G.J. Bouyoucos, A recalibration of the hydrometer method for making mechanical analysis of soils, J. Agronomy 43 (1951) 434-438.

[9] P. Babula, V. Adam, Uncommon heavy metals, metalloids and their plant toxicity: A review, Environ. Chem. Lett. 6 (2008) 189-213.

[10] I.I. Udousoro, I.U. Umoren, E.O. Asuquo, Survey of some heavy metal concentrations in selected soils in south Eastern parts of Nigeria, World J. Appl. Sci. Technol. 2(2) (2010) 139-144.

[11] I. Oguntimehin, K. Ipinmoroti, Profile of heavy metals from automobile workshops in Akure, Nigeria, J. Environ. Sci. Technol. 1(7) (2008) 19-26. 
[12] O. Akoto, J.H. Ephraim, G. Darko, Heavy metals pollution in surface soils in the vicinity of abundant railway servicing workshop in Kumasi, Ghana, Int. J. Environ. Res. 2(4) (2008) 359-364.

[13] J. Wu, Y. Liu, L. Tang, F.L. Zhang, F. Chen, A study on structural features in early flower development of Jatropha curcas L. and the classification of its inflorescences, Afr. J. Agri. Res. 6(2) (2011) 275-284.

[14] J. Kozdroj, Microbial responses to single or successive soil contamination with Cd or Cu, Soil Biol. Biochem. 27 (1995) 1459-1465.

[15] L.C. Osuji, C.M. Onojake, Field reconnaissance and estimation of petroleum hydrocarbon and heavy metal contents of soils affected by the Ebocha- 8 oil spillage in Niger Delta, Nigeria, J. Environ. Manage. 79 (2006) 133-139.

[16] M.A. Nwachukwu, H. Feng, J. Alinnor, Assessment of heavy pollution in soil and their implications within and around mechanic villages, Int. J. Environ. Sci. Technol. 7(2) (2010) 347-358.
[17] C.U. Aguoru, C.A. Alu, Studies on solid waste disposal and management methods in Makurdi and its environs in north central Nigeria, Greener J. Environ. Manage. Pub. Safety 4(2) (2015) 19-27.

[18] D.J. Taylor, N.P.O. Green, G.W. Stout, Biological Sciences, $6^{\text {th }}$ Edn., Cambridge, UK, 2007.

[19] B.J. Alloway, Heavy metals in soils, Integrated Pollution Prevention and Control (IPPC), Best available techniques reference document on the production of iron and steel, Publ: EC European IPPC Bureau, Spain, 1990.

[20] M. Smejkalova, O. Mikanova, L. Boruvka, Effects of heavy metal concentrations on biological activity of soils microorganism, Plant, Soil Environ. 49 (2003) 321-326.

[21] C.U. Aguoru, E.T. Azua, J.O. Olasan, Approaches to minimizing and overcoming current biodiversity loss, Brit. J. Environ. Sci. 3(3) (2015) 12-26.

[22] I.M. Cardoso, T.W. Kuyper, Mycorrhizas and tropical soil fertility, Agri. Ecosys. Environ. 116(1-2) (2006 72-84 